\title{
Books and publishing in the South African trade market: changing writers, changing themes
}

\author{
Author Details \\ Name: Jana Möller \\ Department: Information Science \\ University/Institution: University of Pretoria \\ Town/City: Pretoria \\ Country: South Africa
}

Corresponding author: Jana Möller

Corresponding Author's Email: jana8721@yahoo.com

\section{Biographical Details}

I completed my Bachelor's in Information Science with specialisation in Publishing degree at the University of Pretoria in 2008, and finished my Honours degree in 2010. I also completed my BA Honours in Translation and Professional Writing in 2010. I am currently busy with my MIS degree at the University of Pretoria.

\section{Abstract}

This article investigates the author profiles and writing in South Africa's history, with a special focus changes that have occurred from apartheid to present day. South Africa has gone through a variety of changes in the past decades, including major political changes. This has had a big effect on South African writers and the works they produced and produce today. These changes have also had an effect on language, readers, publishers and the markets for books from South Africa.

This article comes to the conclusion that South African authors have adapted to their environment and their writing is representative of this. While English language books always stayed strong Afrikaans has surged in popularity, and African languages continue to be poorly represented. Authors from all different races and both genders are being published. Themes of books have changed from resistance literature to reconciliation literature. Today literature about political disaster and crime are appearing, and books detailing South Africa's history stay popular among readers. Authors are also attempting 'lighter' material: romance, adventure, crime 
fiction. While there are more women writers on the scene than before, there are still more white women than black women who write. Women are however, still lagging behind men in popularity.

\section{Keywords}

Author profile

Book theme

Afrikaans, English, African languages

South African literature

Apartheid

Article Classification: Research paper

\section{Introduction}

South Africa's publishing history has gone through major changes over especially the last few decades, from apartheid to democracy. The different situations and changes that have come about have had a big effect on South African writers and the works they produced and produce today. Author profiles have changed, and the types of content produced and published today is very different from what was produced and published during apartheid years. These changes have also had an effect on language, on readers, on publishers and the markets for books from South Africa. This article looks into the changes that have taken place with authors and writing with a specific focus on the apartheid years up to present day.

During apartheid writers of all races produced works, although possibly for different reasons or with different purposes: some works were published by the government-supported publishers, others by oppositional publishers or by publishers from abroad, and some works were simply distributed among peers. Writers of novels, short stories and poetry consisted largely of men. There was 
extreme censorship during these times, and many authors were exiled; some South African authors still live abroad today, while others do not publish with South African publishers.

The democracy meant that everybody, men and women of all races, were now equal. Thus everyone could write and produce works, without the censorship laws (like the Publications and Entertainments of 1963) the previous government imposed. However Oliphant claims in his article published in 2000 that "while South Africa has...a strong indigenous publishing sector that developed during the decades of isolation imposed on the country by the cultural and academic boycott, this industry was nevertheless developed to serve the interests of minority domination in the spheres of literary production" $(2000,109)$; some of these legacies still haunt the publishing industry today.

In this paper, Afrikaans, English and African languages are often discussed separately, as their developments and changes have been so closely linked to changes in South African history; changes which influenced them to go on very specific paths.

Historical influences

To understand the changes authors and the kinds of works they write have changed, it is important to understand the history that may have influenced these changes. While apartheid and the later democratic government have brought about some of the most major changes, other events in the history of South Africa are no less important.

\section{Colonial period}

During the British colonial period, expatriates controlled the publishing houses of Africa (Krynauw 1994, 7). These were mostly established Western companies and because of their expertise and financial backing, they were able to create infrastructures in many sectors of the industry. The colonial period was also characterised by "very limited local book production or printing activity" (Hooper 1996, 68). Furthermore, most "printed materials were imported from the home countries" 
(Hooper 1996, 68). Hooper continues to explain that by the second half of the nineteenth century, "religious works in Dutch predominated...reflecting the spread of the Dutch-speaking colonists away from the English colonial powers, and their determination not to lose their cultural identity" (1996, 70). This shows that the introduction of books and publishing in South Africa was controlled by colonialists and European languages like English and Dutch dominated. The first South African newspaper was called The Cape Town Gazette, and later on the newspaper African Advertiser was published in 1800 (Hooper 1996, 69). The first Afrikaans book published was called Zamenspraak tusschen Klaas Waarzegger en Jan Twyfelaar (1861) by L.H. Meurant (a book dealing with the question of partition between the Eastern and Western provinces [February 1991, 78]) and the first book of Afrikaans poetry was called Dertig Liederen (1861) by D.C. Esterhuyse and N.H. Marais (Hooper 1996, 70). It is also important to note that the first missionary press was established in 1823 (Hooper 1996, 70) and that missionary presses were important in the publishing of South Africa's indigenous languages and generally sought to educate black South Africans (Mpe and Seeber 2000,18 in English and other African languages. Indigenous language books were published by missionary presses like Lovedale, who were instrumental in the publishing of especially Xhosa titles. The Glasgow Missionary Society (later Lovedale) published the first Bantu newspaper in 1844, called Ikhwezi ('Morning Star') (Hooper 1996, 70). While missionary publishers were extremely important in the encouragement of indigenous language publishing, their purpose was also religious teachings and an enforcement of western culture, which meant that African culture had to take a back seat. They were controlled and managed by European missionaries, and formed an extension of the colonial order in South Africa - the literature published by the mission presses "invariably centred on propagating Christianity and...Western culture as a value system both superior and preferable to indigenous culture" (Oliphant 2000, 112). 


\section{Post-colonial period}

In post-colonial times, the expatriate publishers maintained their infrastructures and gave assistance by encouraging local authorship, helping to popularise the local languages and training of publishers (Kotei as quoted by Krynauw 1994, 7). However though local languages were supported it was in a specific way; "they held back the developments of the local publishing industry by preventing local decision-making as to what should or should not be published...with little attempt to redress the balance in favour of African needs" (Krynauw 1994, 7). The period from 1910 to 1960 "saw the development of a very strong publishing movement in support of the strong Afrikaner language nationalism which grew after the Anglo-Boer war" (Hooper 1996, 72). The Afrikaans language movement helped start the first Afrikaans newspaper, Die Burger, in 1915. Companies like J.C. Juta, Maskew Miller, the Hollansche-Afrikaansche Uitgevers-Maatschappij and J.L. Van Schaik were all publishing Afrikaans language books in increasing numbers, mostly readers and textbooks (Hooper 1996, 72). The publication of children's series like Monument by Van Schaik and Kennis vir Almal (later developed into a children's encyclopaedia in Afrikaans called Die Afrikaanse Kinderensiklopedie) by Nasionale Pers helped increase print-runs and profitability for publishers (Hooper 1996, 72-73).

National Party-supported Afrikaner publishing houses like Van Schaik and Nasionale Pers dominated the industry in the 1920s and 1930s. When the National Party came into power in 1948, there continued to be nationalist Afrikaans publishing houses, but oppositional publishers like Ad Donker and Ravan Press also came into existence. Hooper claims that "the liberation struggle was almost entirely ideological, so it was understandably focussed on the schools, the universities, and the educational process" $(1996,74)$. While there was growth in the published output of indigenous African languages during apartheid, this growth was controlled and directed towards providing literature for a school market strictly controlled by the government and its objectives (Oliphant $2000,117)$. Censorship was extreme and oppositional publishers fought against the government and 
other publishing houses that supported apartheid rule. The liberation struggle was evident in the publishing and book trade industry (Hooper 1996, 74): "Many South African writers brought the pain and brutality of apartheid into sharp focus through their writings...in many cases, banning [of a book] enhanced the marketability of a book, and gave the author credibility and legitimacy" (Hooper $1996,74)$. Because of the politicisation of books in the country there were many authors who were forced to publish abroad because of bans, but they also published abroad because "publication by the northern anglosphere's leading publishing houses brought wider reviewing opportunities, better sales and access to reader's club or prize endorsements" (Van der Vlies 2012, 707). For example, "a number of Nadine Gordimer's novels were published by Penguin in London, Steve Biko's I write what I like was popularised posthumously...by Heinemann in Oxford and Es'kia Mphahlele's autobiography Down Second Avenue found its way to the reading public through Faber \& Faber in London 1959" (Mpe and Seeber 2000, 23).

The Afrikaans language press that "emerged from the propaganda organs of the National Party (NP)...opposed English-dominated capital and supported Afrikaner capital accumulation" (Tomaselli 1997, 67). "Nevertheless, English capital still constituted the dominant economic fraction" and the "manoeuvring necessary for maintaining this uneasy relationship between English and Afrikaner capital inevitably suppressed black interests" (Tomaselli 1997, 67). There was a battle before and during apartheid not just to do with race but with language; the dominant language putting those speakers in a position of power. Within this fighting for dominance and power, African language literature suffered. A big reason for this was that most mission presses closed under National Party rule. The education of black South Africans was against the National Party government's objectives, and they established language boards created to develop African languages and recommend books to be prescribed by the education departments (Ntshangase as quoted by Mpe and Seeber 2000, 18). "This meant that much of the adventurous, creative writing in African languages produced by missionary presses...was rendered unsaleable" (Mpe and Seeber 2000, 18) and not available to the public. They also made sure to keep the level of English learned at schools low. The suppression of 
race through language started at school level with the Bantu Education Act (1953) which has been "revealed as having created a space for the proliferation of African language publishing while simultaneously drastically reducing the scope of its themes and messages" (Mpe and Seeber 2000, 19). An example of creative writing published before the Bantu Education Act is a novel written by a teacher from Kroonstad, A. C. Jordan. Jordan's Ingqumbo yeminyanya, "the wrath of the ancestors," published in 1940 by the Lovedale Press has come to be recognised as the finest novel ever produced in Xhosa (Opland 1990, 136). This story follows Zwelinzima, a young Mpondomise (a Xhosa tribe) prince who reluctantly leaves the University College of Fort Hare and goes back to the land of his ancestors to take his place as king of the Mpondomise (Moropa \& Nokele 2008, 69). This kind of novel was stopped being produced after the Bantu Education Act. Furthermore the National Party's censorship system resulted in banned authors' works no longer being published or quoted, effectively withholding the work of an entire generation from the local reading public (Morgan 2006, 183). The Drum generation of the 50s was silenced by a stricter enforcement of apartheid policies, resulting in exile or a premature end to the literary activities of authors such as Mphahlele, Maimane, Themba, Nakasa and Matshikiza (Morgan 2006, 183). Hooper claims that

"In a country with writers like Wilbur Smith, André Brink, J.M. Coetzee, Ezekiel Mphahlele, Alan Paton, Olive Schreiner, Uys Krige, Jan Rabie, Etienne le Roux and numerous others, the fiction market became characterised by a genre that was highly politicised, and largely reflective of the conflicts and divisions of the society in which the books were written" $(1996,74)$.

However the political situations created fertile ground for expression through writing, and it has been argued that some of the best works have come out of the difficult political situation - whether expressing frustration or bringing people together who were all in the same boat. Hooper further explains that a

"remarkable phenomenon of the apartheid years was the important political and propaganda role played by poetry in the struggle. There was a flowering of protest poetry published in South Africa during the period and 
publishing houses such as Ravan Press, Ad Donker and David Phillip bravely risked ruin to ensure that publications of relevance to the times were published" $(1996,74)$.

Zuidema confirms that "poetry in particular was widely used as a means of conscientising the masses and rallying them behind the political programmes of the organisations that led the anti-apartheid struggle...poetry continues to be closely linked to the wider social and political processes of the country even after the changes of the 1990s" $(2002,11)$. Works were produced for people abroad to read about what was happening in South Africa, and for distribution among South Africans, to communicate, or to incite. Zuidema explains that even non-writers put their hands to poetry as part of the resistance, so that "many of the poets who emerged during these volatile years of intensified political resistance and guerrilla warfare were not poets pur sang. They saw poetry as part of a wider programme of political and cultural resistance, and tended to combine literary activities with political activism..." $(2002,15)$. Some resistance poetry includes poetry by Sipho Sepamla, whose poetry has been collected in the volumes Hurry Up to It! (1975) and The Soweto I Love (1977), which was banned by the apartheid government; Mongane W. Serote, whose poetry collections include Yakhal'inkomo ('The Cry of Cattle at the Slaughterhouse, 1972) and No Baby Must Weep (1975) and Obuyiseni O. Mtshali whose poetry collections include Sounds of a Cowhide Drum (1971) and Fireflames (1980), which was also banned by the South African government for its antiapartheid sentiment (Poetry Foundation, 2014).

\section{The end of apartheid: books and writers in a democratic South Africa}

When the end of apartheid arrived, a time of change was upon the country. During South Africa's transition years, from 1990-1994, literature came to serve a new role in the changing country - new political circumstances meant new challenges. Resistance literature had changed to literature of reconciliation - and whereas before many authors and poets' work were aimed at specific groups of people (for example white or black people), now works were aimed at all citizens who needed to partake in the changes of South Africa. However, "one of the major questions confronting writers 
from 1990 onward had been the question of what to write about once the dominance of political themes became less pressing and the over-riding urgency of providing political rhetoric in a changed situation of conflict less obvious" (Oliphant 2000, 119). This is a sentiment shared by Hooper: "The great challenge being faced by our contemporary novelists today is to find a new topic to write about now that apartheid has ended" $(1996,74)$ and indeed, the themes of books produced in South Africa have changed much. However, African language titles are almost absent from the trade book market.

Without censorship, authors are free to write in their language of choosing; however black authors' creative expressions in their mother tongues have not reached the wider market as was hoped after apartheid ended. Historically, "creative writing in African languages was encouraged for almost a century before the apartheid regime proceeded with the encouragement albeit also for ulterior ends" (Swanepoel 1996, 22) which means that some development of African languages has taken place - a positive point. On the other hand, "during the apartheid years which held the country captive for almost half a century, emphasis was laid on the development of European culture, and therefore, on creative writing in Afrikaans and English as well as research on them" (Swanepoel 1996, 22). The 'literature in African languages' problem that South Africa is experiencing in the trade sector proves that South African languages now need to be developed more equally - and this goal is yet to be reached. Black authors are often unwilling to write in African languages because of the perceived lack of African language readers, and also because their work is then inaccessible to anyone outside of South Africa, and to many even in South Africa. In 1996, Swanepoel explains in his article that "literature in African languages remain inaccessible to other language groups. Although a firm foundation has been laid as far as translation of African literature into Afrikaans and English is concerned, very few works have hitherto been translated...People should be empowered to access African literature in its own medium" $(1996,67)$. There are however, still few translators proficient enough to translate books from the African languages into good English editions and financial constraint also plays a role in preventing multilingual publishing from becoming more successful in 
this country. A reason given for this situation is that there is not enough reader demand for African language titles. An article written by Eve Horwitz in 1996 highlights more issues that were slow to change. Bookshops were still mostly westernised in appearance and provision of content, with the only changes a few political books on the shelves $(1996,16)$. There may have been marginally more bookshops, but the publishing industry was still predominantly white and provided to a middle class reading public in an ever decreasing circle of diminishing markets $(1996,16)$.

Today South Africa's publishing industry is still driven by the educational sector where most African language publishing takes place; very few African language titles are available in the trade or academic markets and these sectors are dominated by English and Afrikaans titles. In 1989, 78 per cent of all books published in South Africa were written in either English or Afrikaans (Morgan 2006, 183). According to Morgan, this situation of 1989 has not changed fundamentally after 1994, despite the constitutional recognition of nine other South African languages as official languages. [...] The statistics clearly show a healthy production of Afrikaans and English literature in comparison to a very meagre output in the nine different African languages (Van der Waal as quoted by Morgan $2006,183)$. Furthermore there still may be too few bookshops to adequately serve South Africa's population. The scope of themes of books available has definitely changed, albeit that the published languages have remained mostly Afrikaans and English. This perceived lack of reader demand has some of its roots in the history of apartheid, although language development today leaves much to be desired. The Bantu Education Act resulted in African language books being commissioned and prescribed, even though what was being read by learners was censored. This meant that authors could not write what they wanted, and readers lost interest because texts "were filtered to appease political agenda" (Swanepoel 2012, 610). Thus a good reading culture was not developed among black students; in addition, a good reading culture was not developed among their parents either. "In the urban areas where black Africans were forced to reside in segregated townships far from work, with inadequate free time, low wages and a general feeling of want and non-belonging, even the bare essentials were hardly affordable and reading was subject to the struggle for survival" 
(Swanepoel 2012, 610). According to Oliphant, the legacies of a racially-skewed education system, along with the demeaning living conditions of the vast majority of South Africans, have effectively stifled the development of a robust reading- and information-centred culture across all communities in the society" $(2000,109)$.

Publishers are wary of publishing African language books because they explain that reading markets are too small. Publishers are businesses in their own right, and are profit driven. As a result of this believed dearth of adult readers of African-language literature, schools have become the area where African language books were published. Some of the biggest school publishers, and indeed biggest publishers in South Africa, include Via Afrika, Heinemann and Maskew Miller Longman. Today "publishing in the indigenous languages is still relatively underdeveloped" (Oliphant 2000, 110). This means that, while there are more authors of colour in the South African market, and even though eleven languages have been declared equal by government, this does not translate into a bigger variety of languages in books being written.

The power and prestige of languages, their social status, has a lot to do with the languages authors write in. Afrikaans has the advantage of not having to compete with imported books, as Afrikaans books are only published in South Africa, and much has been done to ensure that Afrikaans has a good status among its speakers. English is considered a language of prestige, because understanding and reading English means one is able to function in the business and the international world. Furthermore, "the empowerment of language encouraged the creation of a literature. Language and power is an obvious statement in this discourse - where the use of English as the language of the missionaries created a positive attitude towards this language" (Coetzee 1996, 14). African languages, being oppressed before, seems to have a lower status, and many mother tongue speakers prefer to communicate and read in English. This attitude means that the development of African languages is slow and some may even face extinction. Some believe that South African authors writing in English were better served by apartheid than by contemporary South Africa, as 
political interest in the country during apartheid created a market for books although this interest was mostly restricted to the themes of politics and discrimination (Morgan 2006, 184). Now South Africa is a democratic, third-world country, of no particular international interest. Modern-day Afrikaans and African writers seem to depend on translation into the major languages for economic survival, as they shift their focus to Europe and America as markets for their English and/or translated novels (Morgan 2006, 193). The incentive of literary awards is restricted mostly to English and Afrikaans books; books that are recognised internationally are also not in African languages. However, M-Net awards are also made to recognise novels in the Nguni, Sotho and Xitsonga language groups. Unfortunately there are often too few books to choose from to even award the prizes every year. "In recent years, a number of literary prizes could not be awarded, owing to the lack of novels and poetry published in African languages" (Morgan 2006, 184). Most recently (2014) the M-Net Literary Awards have been suspended indefinitely. As it stands, Afrikaans and English are doing well in the trade market (Afrikaans all local titles and English a mixture of local and imported titles).

Overall, South African literature can be seen as being dominated by white authors writing in Afrikaans or English; of the 19 South African authors' works listed under Africa's 100 best books (fiction and non-fiction) of the 20th century, only two were written in African languages. However, there is a much wider variety of different people writing books in contemporary South Africa, though not often in an African language. Multiple award-winner and black author Zakes Mda writes in English, although he spoke isiXhosa as a child and later Sesotho (Morgan 2006, 181). Authors like NP Maake (writing in Sesotho), Ncedile Saule (writing in isiXhosa) and NG Sibiya (writing in isiZulu) may publish in their mother tongues, but the success comes from being prescribed at school, or the translations of their works making it available to a wider audience. The African language market "may even have shrunk after the introduction of outcomes-based education, the reduction in the number of prescribed works and the waning of serious reading in favour of a popular approach" (Swanepoel 2012, 627). 


\section{Contemporary South African literature}

Twenty years since the start of democracy, local South African literature has changed much in its themes, as is well illustrated by what you can find on bookstores' shelves today. There are often more new local titles produced in Afrikaans than English, because no Afrikaans titles are imported. Post-1994, Afrikaans lost its privileged status as one of only two official languages in the country, as well as the state support that aided the growth of Afrikaans literature in the early years of Afrikaans nationalist reign (Viljoen 2012, 463). "For some writers, this loss of status signalled an opportunity for Afrikaans to free itself from the negative associations of the past" (Viljoen 2012, 463). "The most prominent trends in literature of this period are the revisiting of history, the emergence of new voices and the appearance of a body of texts representing dystopic views on post-apartheid South Africa" (Viljoen 2012, 464). Furthermore "the introduction of a range of new voices to Afrikaans literature after 1990 was partly the result of new strategies by Afrikaans Publishers" and Kwela (a publishing house focused on publishing local content, now owned by NB Publishers) was set up with the brief to focus on the development of new writers and to "give voice to those South Africans who hitherto had not had the opportunity to make themselves heard" (Viljoen 2012, 467). Another trend, according to Viljoen, in especially Afrikaans literature is the "publication of literary texts that reflect on South African society with feelings of disillusion, moral uncertainty and the fear of a political and/or ecological disaster" $(2012,468)$. Afrikaans literature includes works that aimed to preserve a language and culture, and to dissect the past. Reports by the Publishers' Association of South Africa (PASA) highlight that in South Africa, on average, non-fiction is more popular than fiction, most fiction titles are imported, English remains the biggest language when it comes to sales of trade books, even when Afrikaans sometimes sells more fiction or non-fiction titles and Afrikaans has a bigger new title production per year as many English titles are imported. Popular non-fiction titles in Afrikaans include cookbooks, biographies or autobiographies, political or historical titles and true crime for example Moord op Griekwastad - Die storie van die Steenkamp-treurspel (Charné Kemp), Rugbymal: Stories uit die Pawiljoene (Jaco Kirsten), Kwart voor'n Bloedbad (De Wet Potgieter) and 
Boerekos (Cecile Kemp). Interestingly, Oliphant claims that a large part of the Afrikaans language speaking community consist of black people but Afrikaans literature is still produced mostly by white people $(2000,110)$.

Today there are more women writers than ever on the South African literature scene, though still not as many as men - and sometimes they still struggle to get the same accolades as male authors do. There are also some differences in the numbers of black and white women writers. "The postapartheid period has brought new freedom for all of South Africa's women writers, but their published work reveals that black women encounter different problems in their lives from those of white women..." (Hunter and Jonas 2011, 97). Hunter and Jonas claim that black women have a certain obligation that rests on them to write about certain things, like the abuse of a racist government or by "male activist partners" whereas white women have more freedom to write about smaller things "that would previously have been regarded as too frivolous for this country" (2011, 97). They also claim that black women have other obstacles to overcome that white women do not have to: white women have more leisure time to read and write, have the benefits that money can offer like space and equipment and possibly even childcare (Hunter and Jonas 2011,98). While the post-apartheid era brings freedom to all writers, it also means that more people, and significantly black people, are able to receive a tertiary education. However, especially in the case of black women, women have suffered the role of being 'inferior' to men; women's writing will take time to recover - many who have excellent novels are still not as well-known as some established male writers (Hunter and Jonas 2011, 99). “Another hurdle facing black women writers is the fact that despite their country's having eleven official languages, English and Afrikaans dominate within the publishing and bookselling economies" - as mentioned before, this is a problem that does not affect only women writers. Hunter and Jonas (2011) further claim that some white women writers are ready to move away from apartheid in their writing, while black women writers are often still eager to explore this topic and the issues that affected them specifically during this time, but over which 
they had to keep their silence. They categorise post-apartheid works by black women into two groups: novels and short stories set during apartheid and those set in the post 1994 period yet registering the continuing effects of the past $(2011,101)$. Works like crime novels, with a distinctly racial or political slant - issues dealing with by-products of apartheid - are also being produced. Women also launch a "strongly feminist attack on male chauvinism that was impossible to imagine pre-1990" (Hunter and Jonas, 2011, 103). White women often write about guilt and alienation and women's place in South African society, pre and post-apartheid (Hunter and Jonas 2011, 106) but many also just write about things they love, not as tied to the past as black women may be, and are often forward-looking. An example of a successful title written by a black woman is Coconut written by Kopano Matlwa published in 2007, about growing up black in a white suburb. A successful fiction title written by a white woman is Zoo City by Lauren Beukes, a science fiction title set in South Africa published in 2010.

More post-apartheid literature includes stories about the new challenges that arrived with the process of reconciliation, stories about a crime-ridden and violent South Africa. There are stories about on-going farm murders and other non-fiction works, especially books about South African history or political books. There is also an element of hero admiration, especially stories that deal with Nelson Mandela; sports biographies are also very popular. The changes that have come about means that there is more fiction available on the shelves, more comedy, and more crime novels. Authors like Margie Orford, Mike Nicol and Deon Meyer have become very popular crime fiction writers, their novels set in a South African setting - Orford's protagonist being female and Nicol and Meyer's protagonists being male. Angela Makholwa's Red Ink (2007) is South Africa's first crime novel by a black woman (Hunter and Jonas 2011, 111). Also on the shelves, often written by women, are light fiction, fable and fantasy, and stories of family, childhood and place (Hunter and Jonas 2011, 111-113). "Post-1994 writing indeed shows that writers did much to 'write open the country'...Life under apartheid, solidarity of the struggle, frustrated expectations of the new regime, the HIV/AIDS pandemic, society and crime, rape, gayness, unrest and xenophobia, love affairs across 
what was called 'the colour bar' and many others..." (Swanepoel 2012, 620). These are contemporary issues faced by South Africans every day. According to Swanepoel African literatures are alive and responding to "their freedom, to societal realities, and doing so with imagination and freedom" $(2012,627)$ although there are still some challenges they face. Whereas before writers men and women - really had something to write about that evoked strong feelings, today some may even write just for financial reasons.

\section{Conclusion}

Throughout South Africa's publishing history, the State would intervene to safeguard the interests of minority rule (Oliphant 2000, 111), but new political circumstances (changes are still happening today) mean there is a continuing journey in terms of literature, with "the ultimate goal of equality, freedom, prosperity and justice for all..." (Zuidema 2002, 22).

Colonialism brought English and Dutch to South Africa, as well as books imported from the colonialists' home countries. Also through the missionary presses, African language publishing started. Post-colonial times saw further growth of local languages and the Afrikaans language movement. With the National Party coming into power in 1948, there was a definite support of the Afrikaans language and a growth of resistance literature. There was also a movement of African language titles being relegated to the school system.

The end of apartheid brought the end of censorship, and authors could write what they want. There have been many changes from apartheid to democratic South Africa. There are more black authors and more women writing novels; authors have had to reinvent and have had to find new issues that they are passionate about. Resistance literature has changed to reconciliation literature, and today more local fiction titles are available than ever before (as opposed to only historical or political titles, although these remain popular among readers). However, African languages remain in the schools sector, and not many titles are available for mother-tongue leisure readers. There is not much 
poetry on the shelves of bookstores on contemporary South Africa; there is no pressing situation like what apartheid created for poetry to be written specifically; the function of poetry as 'an inciter of masses' has disappeared, and the popularity of poetry, in any language, has waned. Twenty years after apartheid, authors are attempting 'lighter' material, not necessarily connected to South Africa's history: romance, adventure, crime fiction. Women are however, still lagging behind men in popularity, still trying to overcome the preconceived sentiments left over from the past.

South Africa's publishing industry continues to grow. The educational industry is still the largest, but the trade industry is growing in terms of authors and themes; producing internationally recognised authors. However, the country's official languages are not all experiencing exposure in the trade sector: here the market is dominated by English and Afrikaans. The trade sector, and the industry as a whole, has come along in leaps and bounds and yet, there are issues and problems that have remained unchanged or regressed.

\section{Bibliography}

February, V. 1991. The Afrikaners of South Africa. London and New York: Routledge.

Hooper, Anthony S. C. 1996. History of the South African Publishing and Book Trade. In: The Love of Books. Bibliophilia Africana VII. Westra, EP \& Jones, LT. (eds), 67-77. Cape Town: South African Library.

Horwitz, E. 1996.Current Publishing Trends in South Africa. In: The Love of Books. Bibliophilia Africana VII. Westra, EP \& Jones, LT. (eds). Cape Town: South African Library.

Hunter, Eva and Jonas, Siphokazi. 2011. "Breaking the Silence: Black and White Women's Writing". In SA Lit Beyond 2000, edited by Michael Chapman and Margaret Lenta, 97-118. Scottsville: University of KwaZulu-Natal Press. 
Krynauw, P. 1994. "Problems and implications of western dominance in the production and distribution of books in Africa." Innovation no. 8, June 1994: 4-10.

Maake, Nhlanhla. 2000. "Publishing and Perishing: Books, People and Reading in African Languages in South Africa". In The Politics of Publishing in South Africa, edited by Nicholas Evans and Monica Seebe, 127-159. Scottsville: University of Natal Press.

Morgan, Naomi. 2006. "Revisiting the South African book market: towards a change of tongue?" Acta Academica Supplementum 2006(2): 179-196.

Moropa, K. \& Nokele, B. 2008. Shehe! Don't gothere!: AC Jordan's Ingqumbo Yeminyanya (The Wrath of the Ancestors) in English. Southern African Linguistics and Applied Language Studies 26(1): 69-85.

Mpe, Phaswane and Seeber, Monica. 2000. "The Politics of Book Publishing in South Africa: A Critical Overview". In The Politics of Publishing in South Africa, edited by Nicholas Evans and Monica Seeber, 15-42. Scottsville: University of Natal Press.

National English Literary Museum, 2008. South Africa. The Journal of Commonwealth. [Online]. Available: http://intl-jcl.sagepub.com/content/46/4/711.refs.

Oliphant, Andries. 2000. "From Colonialism to Democracy: Writers and Publishing in South Africa". In The Politics of Publishing in South Africa, edited by Nicholas Evans and Monica Seeber, 107-126. Scottsville: University of Natal Press.

Opland, Jeff. 1990. "The Publication of A.C Jordan's Xhosa Novel, 'Ingqumbo yeminyanya (1940)'." Research in African Literatures 21(4): 135-147. [Online]. Available: http://www.jstor.org/stable/3819327. [Accessed 29 May 2014].

Poems \& Poets. Poetry Foundations. [Online]. Available: http://www.poetryfoundation.org/. [Accessed 29 May 2014]. 
Swanepoel, Christiaan F. 1996. “Merging African-language Literature into South African Literary History." In Rethinking South African Literary History, edited by Johannes A. Smit, Johan van Wyk and Jean-Philippe Wade. Durban: Y Press.

Swanepoel, Christiaan. 2012. "African languages and publishing since 1948”. In The Cambridge History of South African Literature, edited by David Attwell and Derek Attridge. New York: Cambridge University Press.

Tomaselli, Keyan. 1997. "Ownership and control in the South African print media: black empowerment after apartheid, 1990-1997." Ecquid Novi: African Journalism Studies 18(1): 67-68.

Van der Vlies, Andrew. 2012. "South Africa in the Global Imaginary". In The Cambridge History of South African Literature, edited by David Attwell and Derek Attridge. New York: Cambridge University Press.

Viljoen, Louise. 2012. "Afrikaans Literature after 1976". In The Cambridge History of South African Literature, edited by David Attwell and Derek Attridge. New York: Cambridge University Press.

Zuidema, Ritske. 2002. The changing role of Poetry in the struggle for freedom, justice \& equality in South Africa. In South \& Southern African Literature, edited by Eldred D. Jones and Marjorie Jones. Oxford: James Currey Ltd. 